\title{
Upregulation of rhoA mRNA in Bronchial Smooth Muscle of Antigen-induced Airway Hyperresponsive Rats
}

\author{
Yoshihiko CHIBA ${ }^{1}$, Hiroyasu SAKAI ${ }^{1}$, Hiroshi WACHI ${ }^{2}$, \\ Hideki SUGITANI $^{2}$, Yoshiyuki SEYAMA ${ }^{2}$ and Miwa MiSAWA ${ }^{1}$ \\ ${ }^{1}$ Department of Pharmacology, School of Pharmacy, Hoshi University, 2-4-41 Ebara, \\ Shinagawa-ku, Tokyo 142-8501, Japan \\ ${ }^{2}$ Department of Clinical Chemistry, School of Pharmacy, Hoshi University, 2-4-41 \\ Ebara, Shinagawa-ku, Tokyo 142-8501, Japan
}

\begin{abstract}
It has recently been suggested that RhoA plays an important role in the enhancement of $\mathrm{Ca}^{2+}$ sensitization observed in smooth muscle contraction. In the present study, the expression of $r h o A$ mRNA in the bronchial smooth muscle of antigen-induced airway hyperresponsive rats was compared with that of control animals. Reverse transcriptionpolymerase chain reaction experiments using total RNA from these tissue specimens and the specific primers revealed rhoA mRNA to be expressed in bronchial smooth muscle of the rat. The $r h o A$ mRNA expression in bronchial smooth muscle of the hyperresponsive rats was significantly increased in comparison to that of control animals. It is thus possible that upregulation of RhoA protein might be involved in the mechanism underlying the increased contractility of the bronchial smooth muscle which occurs with airway hyperresponsiveness.
\end{abstract}

Key words: asthma, airway hyperresponsiveness, bronchial smooth muscle, $\mathrm{Ca}^{2+}$ sensitization, RhoA, mRNA

\section{Introduction}

Smooth muscle contraction is mainly regulated by an increase in the concentration of cytosolic $\mathrm{Ca}^{2+}$. Recently, additional mechanisms have been suggested in agonist-induced smooth muscle contraction as a result of studies which used the simultaneous measurement of force development and intracellular $\mathrm{Ca}^{2+}$ concentration, as well as those on various smooth muscle preparations which have been chemically permeabilized. It has been demonstrated that agonist stimulation increases myofilament $\mathrm{Ca}^{2+}$ sensitivity in $\beta$-escin-permeabilized smooth muscle of the rat coronary artery (Satoh et al., 1994), guinea pig vas deferens (Fujita $e t$ al., 1995), canine trachea (Bremerich et al., 1997) and rat bronchus (Chiba et al., 1999b). Although the detailed mechanism is not fully understood, many investigators have suggested the

Correspondence to: Y. Chiba, Ph.D., Department of Pharmacology, School of Pharmacy, Hoshi University,

2-4-41 Ebara, Shinagawa-ku, Tokyo 142-8501, Japan

Phone: 81-3-5498-5786 Fax: 81-3-5498-5787 e-mail: chiba@hoshi.ac.jp 
participation of RhoA, a monomeric GTP binding protein, in the agonist-induced $\mathrm{Ca}^{2+}$ sensitization (e.g., Fujita et al., 1995; Gong et al., 1997; Chiba et al., 1999b).

Asthmatic patients have an increased contractility of airway smooth muscle (Roberts $e t$ al., 1984), which might be a major cause of airway hyperresponsiveness (AHR). Similarly, an increased responsiveness of bronchial smooth muscle has been demonstrated in a rat model of AHR induced by repeated antigen inhalation (Chiba and Misawa, 1995a, b). In AHR rats, it has also been demonstrated that acetylcholine-induced RhoA-mediated $\mathrm{Ca}^{2+}$ sensitization is markedly augmented concomitantly with an increased expression of RhoA protein in the bronchial smooth muscle (Chiba et al., 1999b). It is thus possible that the upregulation of RhoA protein in airway smooth muscle might be an essential event in the pathogenesis of AHR. However, the level of expression of $r h o A$ mRNA in AHR has not yet been elucidated. In the present study, we have examined the level of expression of $r h o A$ mRNA in the bronchial smooth muscle of antigen-induced AHR rats.

\section{Methods}

\section{Sensitization and antigenic challenge}

Male Wistar rats (6 weeks of age, specific pathogen-free, 170-190 g, Charles River Japan, Inc.) were sensitized and repeatedly challenged with 2,4-dinitrophenylated Ascaris suum antigen (DNP-Asc) by the method described in our previous papers (Chiba \& Misawa, 1995a,b; Chiba et $a l ., 1999 \mathrm{~b})$. Age-matched non-sensitized normal animals were used as controls (Chiba and Misawa, 1995a,b; Chiba et al., 1999b).

\section{Isolation of total RNA}

Twenty-four hours after the last antigen challenge, bronchial tissue preparations were prepared in essentially the manner described previously (Chiba et al., 1999b). In brief, the airway system below the main bronchi to the lungs was removed and immediately soaked in icecold, oxygenated Krebs-Henseleit solution (118.0 mM NaCl, $4.7 \mathrm{mM} \mathrm{KCl}, 2.5 \mathrm{mM} \mathrm{CaCl}$, $1.2 \mathrm{mM}$

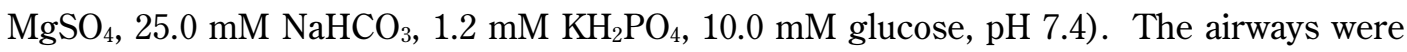
carefully cleaned of adherent connective tissue, blood vessels and lung parenchyma using a stereomicroscope. The airway epithelium was removed as completely as possible by gently rubbing with a pair of keen-edged tweezers (Chiba et al., 1999b). Then the bronchial segments (containing main and intrapulmonary bronchi) were quickly frozen with liquid nitrogen, and the tissue crushed using a Cryopress ${ }^{\mathrm{TM}}$ (CP-100W; Niti-on, Co. Ltd., Japan: $15 \mathrm{sec} \times 3$ ). Total RNA extraction was performed on each frozen tissue sample using the acid guanidium thiocyanate/ phenol/chloroform method (Chomczynski and Sacchi, 1987) and stored at $-85^{\circ} \mathrm{C}$ until use. The total RNA experiments were performed on extracts from 5 different animals, and the mean \pm s.e.m. determined.

\section{Reverse transcription-polymerase chain reaction ( $R T-P C R$ )}

The level of rhoA mRNA was examined by RT-PCR, a simple method that is widely used for semi-quantitative measurement of mRNA levels (e.g., Niiro et al., 1997; Ma et al., 2002; Murray 
et al., 2002; Chen et al., 2003; Medina et al., 2003; Zhu et al., 2003). Briefly, cDNAs were prepared from the total RNA $(0.5 \mu \mathrm{g})$ by using a Takara RNA PCR Kit (Ver. 2.1; Takara, Tokyo, Japan) in a total volume of $20 \mu \mathrm{l}$ reaction buffer containing $10 \mathrm{mM}$ Tris- $\mathrm{HCl}, \mathrm{pH} 8.3,50 \mathrm{mM} \mathrm{KCl}$, $5 \mathrm{mM} \mathrm{MgCl}_{2}, 1 \mathrm{mM}$ dNTP mixture, $1 \mathrm{U}^{-1} \mathrm{l}^{-1}$ Rase inhibitor, $2.5 \mu \mathrm{M}$ random 9 mers and $0.25 \mathrm{U}$ $\mu \mathrm{l}^{-1}$ avian myeloblastosis virus reverse transcriptase. The reaction mixture was incubated for 10 min at $30^{\circ} \mathrm{C}$ followed by $60 \mathrm{~min}$ at $42^{\circ} \mathrm{C}$ to initiate the synthesis of the cDNAs. Reverse transcriptase was inactivated at $99^{\circ} \mathrm{C}$ for $5 \mathrm{~min}$. Then the followings were added to the RT reaction mixture $(10 \mu \mathrm{l}): 0.5 \mu \mathrm{l}$ of $0.1 \mathrm{mM}$ forward primer, $0.5 \mu \mathrm{l}$ of $0.1 \mathrm{mM}$ reverse primer, $4 \mu \mathrm{l}$ of $10 \times$ amplification buffer ( $100 \mathrm{mM}$ Tris- $\mathrm{HCl}, \mathrm{pH} 8.3,0.5 \mathrm{M} \mathrm{KCl}), 3 \mu \mathrm{l}$ of $25 \mathrm{mM} \mathrm{MgCl}_{2}, 31.8 \mu \mathrm{l}$ of $\mathrm{H}_{2} \mathrm{O}$, and $0.25 \mu \mathrm{l}$ of $5 \mathrm{U}^{-1} \mathrm{Taq}$ polymerase. The PCR primers for rat $r h o A$ were 5'GTGATTGTTGGTGATGGAGC-3' (sense) and 5'CTCGTGGCCATCTCAAAAAC-3' (antisense) (Yoshimura et al., 1997). The PCR primers for rat glyceraldehyde-3-phosphate dehydrogenase (GAPDH) were 5'-CCATCACTGCCACTCAGAAGAC-3' (sense) and 5'TACTCCTTGGAGGCCATGTAGG-3' (antisense), which were designed from published sequences. The thermal cycle profile used in the present study was: 1) denaturing for $30 \mathrm{sec}$ at $95^{\circ} \mathrm{C}$, 2) annealing the primers for $30 \mathrm{sec}$ at $60^{\circ} \mathrm{C}$ and then 3) extending the primers for $60 \mathrm{sec}$ at $72^{\circ} \mathrm{C}$. PCR amplifications were performed for $15,20,25,30$ and 35 cycles. A portion $(10 \mu \mathrm{l})$ of the PCR mixture was subjected to electrophoresis on $2 \%$ agarose gel (E-Gel ${ }^{\mathrm{TM}}$; Invitrogen, CA, USA) and visualized by ethidium bromide staining. The intensity of bands was quantified by a densitometer (Atto Densitograph; Atto Co., Tokyo, Japan). The ratios of the corresponding $r h o A / G A P D H$ were calculated as indices of $r h o A$ mRNA levels.

\section{Statistical analyses}

All the data are expressed as the mean \pm standard error of the mean (s.e.m.). Statistical significance of differences was determined by Dunnett's multiple analysis.

\section{Results}

Figure 1 shows the expression of $r h o A$ and GAPDH mRNAs in the rat bronchial smooth muscle, as determined by RT-PCR using the total RNA estimated in preparations from nonsensitized normal rats. The PCR amplifications were performed for 15, 20, 25, 30 and 35 cycles. Bands for rhoA (503 bp) and GAPDH (468 bp) were clearly detected in the rat bronchial smooth muscle at a size close to that predicted (Fig. 1a). Both the band intensities for $r h o A$ and GAPDH were PCR amplification-cycle-dependently increased and had nearly reached a plateau by 30-35 and 30 cycles, respectively (Fig. 1b). On the other hand, the PCR products obtained without RT reaction had no distinct bands (lanes 6 and 11 of Fig. 1a), indicating that there was no genomic DNA contamination in the RNA samples used in the present study.

In order to estimate the extent of the expression of $r h o A$ mRNA, the ratios of the band intensity of $r h o A$ mRNA to that of GAPDH were calculated. Our previous study revealed that the antigen sensitization procedure used in the present study had no significant effect by itself on either the ACh responsiveness of rat bronchial smooth muscle or on their muscarinic receptor properties (Chiba and Misawa, 1995a). So in the present study, age-matched non- 
a)
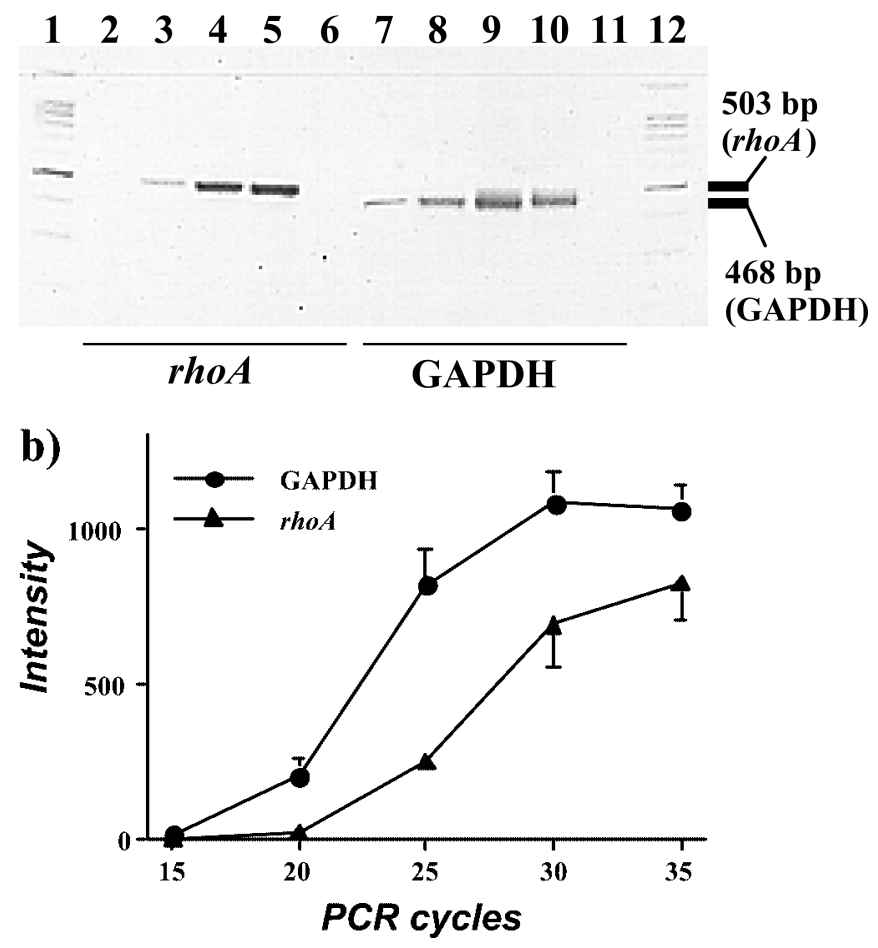

Fig. 1. a) Detection of $r h o A$ (lanes 2-6) and GAPDH (as an inner control; lanes 7-11) mRNAs by RT-PCR in bronchial smooth muscle preparations of control (nonsensitized, normal) rats. PCR amplifications for $r h o A$ and GAPDH were performed for 20 (lanes 2 and 7), 25 (lanes 3 and 8), 30 (lanes 4 and 9) and 35 cycles (lanes 5, 6, 10 and 11), respectively. The predicted sizes of each PCR product are shown beside the photograph. Lanes 6 and 11 represent a negative control, where the RT reaction was performed in the absence of the reverse transcriptase. Lanes 1 and 12 represent the DNA size marker (100 bp DNA ladder). b) The PCR cycle-dependency on the amplifications of the synthesized cDNAs for rhoA (triangles) and GAPDH (circles). The total RNA experiments were performed on extracts from 5 different animals, and the mean \pm s.e.m. shown.

sensitized normal rats were used as controls. The PCR amplifications were performed for 25 cycles, respectively, which showed submaximal but distinct bands (Fig. 1). As shown in Fig. 2, the level of mRNA expression of $r h o A$ was significantly increased in the bronchial smooth muscle of repeatedly antigen-challenged rats. The band intensity for $r h o A$ of the antigen-treated rats $(395.2 \pm 34.9, \mathrm{n}=5)$ was significantly increased when compared to that of the control animals $(247.4 \pm 25.4, \mathrm{n}=5, \mathrm{P}<0.01)$, whereas the band intensity for GAPDH was at an equivalent level (734.6 \pm 93.6 and $818.2 \pm 115.7, \mathrm{n}=5$, respectively).

\section{Discussion}

The present study has clearly demonstrated the upregulation of the expression of $r h o A$ 
a)
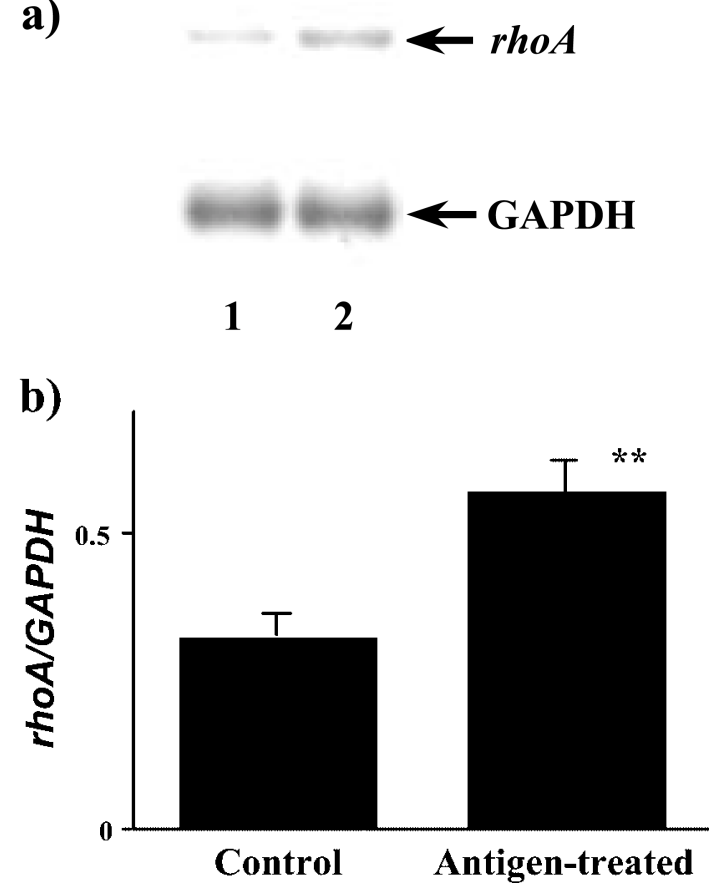

Fig. 2. The level of expression of $r h o A$ mRNA in bronchial smooth muscle from nonsensitized normal (Control) and repeatedly antigen-challenged rats (Antigentreated). a) Typical photographs of RT-PCR product bands for $r h o A$ (upper) and GAPDH (lower) mRNAs. The PCR amplifications were performed for 25 cycles, respectively. The bands were scanned and the level of $r h o A$ mRNA expression was expressed as density ratio of the $r h o A$ to the GAPDH bands and the data were summarized in b). The total RNA experiments were performed on extracts from 5 different animals, and the mean \pm s.e.m. shown. The expression of $r h o A$ mRNA is significantly increased in the bronchial smooth muscle of antigen-treated rats as compared to that of control animals $(\mathrm{P}<0.01)$.

mRNA in bronchial smooth muscle of antigen-induced AHR rats. We previously reported an involvement of RhoA-mediated $\mathrm{Ca}^{2+}$ sensitization in agonist-induced contraction of bronchial smooth muscle in AHR rats and an augmentation of the $\mathrm{Ca}^{2+}$ sensitizing effect, together with an upregulation of RhoA protein (Chiba et al., 1999b). We have shown that the increased expression of $r h o A$ mRNA in the bronchial smooth muscle causes an upregulation of RhoA protein, resulting in an augmented contraction in the AHR by the enhancement of RhoAmediated $\mathrm{Ca}^{2+}$ sensitization.

In smooth muscle, Hirata et al. (1992) first reported that a small GTPase, RhoA, is involved in the mechanism for the increased sensitization of myofilament $\mathrm{Ca}^{2+}$. It was then shown that RhoA is responsible for the inhibition of myosin light chain phosphatase through the activation of Rho-associated kinases (Kimura et al., 1996). The RhoA-mediated $\mathrm{Ca}^{2+}$ sensitization in agonist-induced contraction has also been reported in airway smooth muscle (Chiba et al., 1999b; lizuka et al., 1999; Yoshii et al., 1999; Yamagata et al., 2000). On the other hand, an increase in the responsiveness of airway smooth muscle to contractile agonists has been 
demonstrated in animal models of AHR (Gavett et al., 1993; Lee et al., 1994; Chiba and Misawa, 1995a, b) and asthmatic patients (Roberts et al., 1984), although no change in the levels of plasma membrane receptors was observed (Gavett et al., 1993; Lee et al., 1994; Chiba and Misawa, 1995a). Moreover, the agonist-stimulated increase in the cytosolic $\mathrm{Ca}^{2+}$ level was within the normal range even in the hyperresponsive bronchial smooth muscle (Chiba et al., 1999a). Thus, it is likely that the enhanced contractility to agonists reflects, at least in part, the augmentation of RhoA-mediated $\mathrm{Ca}^{2+}$ sensitization. In fact, we have clearly demonstrated the upregulation of both RhoA protein (Chiba et al., 1999b) and rhoA mRNA (in the current study) in the bronchial smooth muscle of AHR rats. Although the mechanism of transcription of rhoA mRNA in the airway smooth muscle is presently unclear, it might be important to clarify the transcriptional mechanism to enable an understanding of the underlying mechanism involved in the augmented bronchial smooth muscle contraction in the AHR.

An increased expression of $r h o A$ mRNA associated with augmentation of smooth muscle contractility has also been reported in both the rat myometrium during pregnancy (Niiro et al., 1997) and the dog femoral artery in heart failure (Hisaoka et al., 2001). Thus, the upregulation of RhoA might be widely involved in enhanced contraction of abnormal smooth muscle including that of hyperresponsive bronchial smooth muscle.

\section{Acknowledgements}

We thank Ms. Natsuki Kondoh and Ms. Yuko Watanabe for their technical assistance. This work was supported by a Grant-in-Aid for Encouragement of Young Scientists from the Ministry of Education, Science, Sports and Culture of Japan and the Pharmacological Research Foundation, Tokyo, Japan.

\section{References}

Bremerich, D.H., Warner, D.O., Lorenz, R.R., Shumway, R. and Jones, K.A. (1997). Role of protein kinase $\mathrm{C}$ in calcium sensitization during muscarinic stimulation in airway smooth muscle. $\mathrm{Am}$. J. Physiol. 273: L775-L781.

Chen, D., Balyakina, E.V., Lawrence, M., Christman, B.W. and Meyrick, B. (2003). Cyclooxygenase is regulated by ET-1 and MAPKs in peripheral lung microvascular smooth muscle cells. Am. J. Physiol. 284: L614-L621.

Chiba, Y. and Misawa, M. (1995a). Characteristics of muscarinic cholinoceptors in airways of antigeninduced airway hyperresponsive rats. Comp. Biochem. Physiol. 111C: 351-357.

Chiba, Y. and Misawa, M. (1995b). Alteration in $\mathrm{Ca}^{2+}$ availability involved in antigen-induced airway hyperresponsiveness in rats. Eur. J. Pharmacol. 278: 79-82.

Chiba, Y., Sakai, H., Suenaga, H., Kamata, K. and Misawa, M. (1999a). Enhanced Ca ${ }^{2+}$ sensitization of the bronchial smooth muscle contraction in antigen-induced airway hyperresponsive rats. Res. Commun. Mol. Pathol. Pharmacol. 106: 77-85.

Chiba, Y., Takada, Y., Miyamoto, S., Mitsui-Saito, M., Karaki, H. and Misawa, M. (1999b). Augmented acetylcholine-induced, Rho-mediated $\mathrm{Ca}^{2+}$ sensitization of bronchial smooth muscle contraction in antigen-induced airway hyperresponsive rats. Br. J. Pharmacol. 127: 597-600.

Chomczynski, P. and Sacchi, N. (1987). Single-step method of RNA isolation by acid guanidinium 
thiocyanate-phenol-chloroform extraction. Anal. Biochem. 162: 156-159.

Fujita, A., Takeuchi, T., Nakajima, H., Nishio, H. and Hata, F. (1995). Involvement of heterotrimeric GTP-binding protein and rho protein, but not protein kinase $\mathrm{C}$, in agonist-induced $\mathrm{Ca}^{2+}$ sensitization of skinned muscle of guinea pig vas deferens. J. Pharmacol. Exp. Ther. 274: 555561.

Gavett, S.H. and Wills-Karp, M. (1993). Elevated lung G protein levels and muscarinic receptor affinity in a mouse model of airway hyperreactivity. Am. J. Physiol. 265: L493-L500.

Gong, M.C., Fujihara, H., Somlyo, A.V. and Somlyo, A.P. (1997). Translocation of rhoA associated with $\mathrm{Ca}^{2+}$ sensitization of smooth muscle. J. Biol. Chem. 272: 10704-10709.

Hirata, K., Kikuchi, A., Sasaki, T., Kuroda, S., Kaibuchi, K., Matsuura, Y., Seki, H., Saida, K. and Takai, Y. (1992). Involvement of rho p21 in the GTP-enhanced calcium ion sensitivity of smooth muscle contraction. J. Biol. Chem. 267: 8719-8722.

Hisaoka, T., Yano, M., Ohkusa, T., Suetsugu, M., Ono, K., Kohno, M., Yamada, J., Kobayashi, S., Kohno, M. and Matsuzaki, M. (2001). Enhancement of Rho/Rho-kinase system in regulation of vascular smooth muscle contraction in tachycardia-induced heart failure. Cardiovasc. Res. 49: 319-329.

Iizuka, K., Yoshii, A., Samizo, K., Tsukagoshi, H., Ishizuka, T., Dobashi, K., Nakazawa, T. and Mori, M. (1999). A major role for the Rho-associated coiled coil forming protein kinase in G-proteinmediated $\mathrm{Ca}^{2+}$ sensitization through inhibition of myosin phosphatase in rabbit trachea. $\mathrm{Br}$. J. Pharmacol. 128: 925-933.

Kimura, K., Ito, M., Amano, M., Chihara, K., Fukata, Y., Nakafuku, M., Yamamori, B., Feng, J., Nakano, T., Okawa, K., Iwamatsu, A. and Kaibuchi, K. (1996). Regulation of myosin phosphatase by Rho and Rho-associated kinase (Rho-kinase). Science 273: 245-248.

Lee, J.Y., Uchida, Y., Sakamoto, T., Hirata, A., Hasegawa, S. and Hirata, F. (1994). Alteration of G protein levels in antigen-challenged guinea pigs. J. Pharmacol. Exp. Ther. 271: 1713-1720.

Ma, X., Cheng, Z., Kong, H., Wang, Y., Unruh, H., Stephens, N.L. and Laviolette, M. (2002). Changes in biophysical and biochemical properties of single bronchial smooth muscle cells from asthmatic subjects. Am. J. Physiol. 283: L1181-L1189.

Medina, R.A., Meneses, A.M., Vera, J.C., Guzman, C., Nualart, F., Astuya, A., de Los Angeles Garcia, M., Kato, S., Carvajal, A., Pinto, M. and Owen, G.I. (2003). Estrogen and progesterone up-regulate glucose transporter expression in ZR-75-1 human breast cancer cells. Endocrinol. 144: 45274535.

Murray, F., MacLean, M.R. and Pyne, N.J. (2002). Increased expression of the cGMP-inhibited cAMPspecific (PDE3) and cGMP binding cGMP-specific (PDE5) phosphodiesterases in models of pulmonary hypertension. Br. J. Pharmacol. 137: 1187-1194.

Niiro, N., Nishimura, J., Sakihara, C., Nakano, H. and Kanaide, H. (1997). Up-regulation of rhoA and rhokinase mRNAs in the rat myometrium during pregnancy. Biochem. Biophys. Res. Commun. 230: 356-359.

Roberts, J.A., Raeburn, D., Rodger, I.W. and Thomson, N.C. (1984). Comparison of in-vivo responsiveness and in-vitro smooth muscle sensitivity to methacholine. Thorax 39: 837-843.

Satoh, S., Kreutz, R., Wilm, C., Ganten, D. and Pfitzer, G. (1994). Augmented agonist-induced Ca ${ }^{2+}-$ sensitization of coronary artery contraction in genetically hypertensive rats. Evidence for altered signal transduction in the coronary smooth muscle cells. J. Clin. Invest. 94: 1397-1403.

Yamagata, S., Ichinose, M., Sugiura, H., Koarai, A., Koike, K. and Shirato, K. (2000). Effect of calcium sensitization modulator, Y-27632, on isolated human bronchus and pulmonary artery. Pulm. Pharmacol. Ther. 13: 25-29.

Yoshii, A., Iizuka, K., Dobashi, K., Horie, T., Harada, T., Nakazawa, T. and Mori, M. (1999). Relaxation of contracted rabbit tracheal and human bronchial smooth muscle by Y-27632 through inhibition of $\mathrm{Ca}^{2+}$ sensitization. Am. J. Respir. Cell Mol. Biol. 20: 1190-1200.

Yoshimura, S.-I., Sakai, H., Nakashima, S., Nozawa, Y., Shinoda, J., Sakai, N. and Yamada, H. (1997). 
Differential expression of Rho family GTP-binding proteins and protein kinase C isozymes during C6 glial cell differentiations. Mol. Brain Res. 45: 90-98.

Zhu, Y.M., Bradbury, D.A., Pang, L. and Knox, A.J. (2003). Transcriptional regulation of interleukin (IL)8 by bradykinin in human airway smooth muscle cells involves prostanoid-dependent activation of AP-1 and nuclear factor (NF)-IL-6 and prostanoid-independent activation of NF-kappaB. $J$. Biol. Chem. 278: 29366-29375.

(Received September 5, 2003; Accepted October 11, 2003) 